\title{
HIGH TEMPERATURE COMPONENTS OF MAGMA- RELATED GEOTHERMAL SYSTEMS: AN EXPERIMENTAL AND THEORETICAL APPROACH
}

Philip A. Candela

Philip M. Piccoli

Summary

$\therefore$ \#DEFGOMOID13025 


\section{SECTION I: Executive Summary}

This summarizes select components of a multi-faceted study of high temperature magmatic fluid behavior in shallow, silicic, volcano-plutonic geothermal systems. This work built on a foundation provided by DOE-supported advances made in our lab in understanding the physics and chemistry of the addition of $\mathrm{HCl}$ and other chlorides into the high temperature regions of geothermal systems. The emphasis of this project was to produce a model of the volatile contributions from felsic magmatic systems to geothermal systems.

The proposed research included work on $\mathrm{HCl}$ - and $\mathrm{H}_{2} \mathrm{SO}_{4}$-bearing brine alteration of silicates at $500{ }^{\circ} \mathrm{C}$ and 500 bars (e.g. Hall, 1999; Frank et al., 1998) and work on the relationship between melt aluminosity and $\mathrm{HCl}$ in the magmatic volatile phase (e.g. Piccoli et al., 1999; Williams et al., 1997).

Successful integration of laboratory and theoretical approaches is critical to the prediction of magmatic-hydrothermal effects in geothermal systems, particularly with respect to how magmatic/high-temperature input to geothermal systems can affect the sulfate and chlorideassociated acidity. This work will be performed at The University of Maryland at College Park primarily by Drs. Philip Candela (Professor of Geology) and Philip Piccoli (Assistant Research Scientist), and by graduate students under our direction. 


\section{SECTION II: Experimental Studies of Brine $\forall$ Solid $\forall$ Melt Systems}

Over the past several years, we have characterized critical parameters related to the chloride acidity of magmatic contributions to geothermal systems. Given that a significant proportion of the acidity in magmatic hydrothermal systems is sulfur-acidity, we explored the chemical properties of sulfate in vapor undersaturated brines, including their reaction with assemblages of rock-forming minerals, likely to be found associated with geothermal reservoirs. We studied brine interactions with amphibole and biotite-bearing assemblages in the system $\mathrm{KCl}-\mathrm{NaCl}-\mathrm{H} 2 \mathrm{O}-\mathrm{HCl}-\left(\mathrm{SO}_{4} \mathrm{Cl}_{2}\right)$ near vapor saturation. We employed high ratios of brine to minerals, as in the study of Frank et al. (1998) to map out mineral stability. Our experiments were performed at salinities near the vapor-saturated boundary, and were conducted in Pt capsules. We utilized an Ar pressure medium with hematite as a $\mathrm{H}_{2}$ "getter" to maintain sulfate stability.

In our experiments, we have mapped out regions of amphibole (tremolite) reactivity in $\mathrm{H} / \mathrm{K}$ and $\mathrm{SO}_{4}=\mathrm{Cl}$ - space. We evaluated the composition of brines in the equilibrium:

$$
\text { tremolite }+\mathrm{H}_{2} \mathrm{SO}_{4}+\mathrm{K} \text {-feldspar }<==>\text { phlogopite }+ \text { quartz }+ \text { anhydrite }
$$

We also mapped out the stability of $\mathrm{k}$-feldspar-muscovite-andalusite-quartz as a function of brine composition in synthetic geothermal systems at temperatures of $400-550^{\circ} \mathrm{C}$, and pressures of 25-60 MPa.

We also performed experiments at $800{ }^{\circ} \mathrm{C}$ and $100 \mathrm{MPa}$ on the relationship between the molar $\mathrm{Al} / \mathrm{K}+\mathrm{Na}+2 \mathrm{Ca}$ ratio in melts and the composition of vapor-undersaturated brines. Some of the aluminosity ( $\mathrm{ASI}=.93$ to 1.00 ) is due to chlorine incorporated into the melt as $\mathrm{NaCl}$. These 
experiments have been run with molar $\mathrm{K}-\mathrm{Na}$ ratios of the brine equal to unity, and melt compositions defined by the $100 \mathrm{MPa}$ granite minimum. Under these conditions, melts remain peralkaline even at high concentrations of $\mathrm{HCl}$ in the brine.

We have applied these systematics to igneous intrusions in the Sierra Nevada batholith. Our calculations show that aqueous magmatic fluids evolved from the Billy Lake-Rush Creek magma had a concentration of $\mathrm{HCl}$ in the vapor phase of 0.02 molal.

\section{Select Milestones:}

\section{Reactions between a sulfate-bearing, vapor-undersaturated brine and the mineral assemblage potassium feldspar-albite-quartz-tremolite-apatite at $500^{\circ} \mathrm{C}$ and 50} MPa.

Hall, $M$.

Sulfate-bearing hydrothermal fluids can be observed at the surface of the earth (i.e. volcanic aerosols and hot springs); however, little is understood about deep, high-temperature $\left(\sim 500^{\circ} \mathrm{C}\right)$, sulfate-bearing brines. Potassically altered mineral assemblages containing hydrothermal "shreddy" biotite are commonly observed in porphyry copper deposits, and are associated with brine-bearing fluid inclusions. In many systems the alteration occurs near the magnetite-hematite oxygen fugacity buffer, and the brines clearly contained dissolved sulfur. In order to constrain the concentration of sulfate in the brine phase responsible for this type of alteration, we performed experiments between minerals and brine with variable sulfate to chloride ratios. We examined the equilibrium: $4 \mathrm{H}_{2} \mathrm{O}+5 \mathrm{KMg}_{3} \mathrm{Si}_{3} \mathrm{AlO}_{10}(\mathrm{OH})_{2}+24 \mathrm{SiO}_{2}+$ $6 \mathrm{CaSO}_{4}=3 \mathrm{Ca}_{2} \mathrm{Mg}_{5} \mathrm{Si}_{8} \mathrm{O}_{22}(\mathrm{OH})_{2}+5 \mathrm{KAlSi}_{3} \mathrm{O}_{8}+6 \mathrm{H}_{2} \mathrm{SO}_{4}$, at $500^{\circ} \mathrm{C}$ and $50 \mathrm{MPa}$. The brine consisted of $\mathrm{NaCl}, \mathrm{KCl}, \mathrm{H}_{2} \mathrm{SO}_{4}$, and $\mathrm{Na}_{2} \mathrm{SO}_{4}$, and the salinity of the brine was held constant at 42 wt.\% $\mathrm{NaCl}$ equivalent (on an equal anion mole basis). The sulfate concentration and the acidity of each experiment were systematically changed by varying $\mathrm{SO}_{4} / \mathrm{Cl}$ and $\mathrm{H} / \mathrm{K}$, respectively, of the 
brine. Phlogopite nucleation was not detected in any of the experimental runs; however, runs seeded with phlogopite showed no obvious signs of phlogopite destruction. Furthermore, in all the runs with $\mathrm{H} / \mathrm{K}<0.09 \pm 0.01$ no mineral alteration was observed. Conversely, in all the runs with the ratio of $\mathrm{H} / \mathrm{K}>0.09 \pm 0.01$, talc was observed to have nucleated on tremolite. We hypothesize that talc may be a metastable, pre-phlogopite phase that nucleates preferentially to phlogopite.

\section{K-feldspar-muscovite-andalusite-quartz-brine phase equilibria: an experimental study at 25 to $60 \mathrm{MPa}$ and 400 to $550^{\circ} \mathrm{C}$}

Frank, M.R., Candela, P.A., and Piccoli, P.M.

Felsic magmas may evolve one or more water or chlorine-rich fluid phases which can transport heat and solutes into associated hydrothermal systems and can contribute to alteration and ore deposition. To understand the role of a high-salinity aqueous phase in the magmatic hydrothermal environment, the composition of a subcritical, vapor-undersaturated high-salinity liquid phase (brine) in equilibrium with $\mathrm{K}$-feldspar-muscovite-quartz and muscovite-andalusitequartz was determined for pressures and temperatures ranging from $25 \mathrm{MPa}$ and $400^{\circ} \mathrm{C}$ to 60 $\mathrm{MPa}$ and $550^{\circ} \mathrm{C}$, with total $\mathrm{Cl}(\mathrm{NaCl}+\mathrm{KCl}+\mathrm{HCl})$ concentrations ranging from 3.42 to 8.56 (moles of solute/kg solution). Values of $\log 10(\mathrm{KCl} / \mathrm{HCl})$ have been obtained for the equilibria: $1.5 \mathrm{~K}$-feldspar $+\mathrm{HCl}=0.5$ muscovite +3 quartz $+\mathrm{KCland}$ muscovite $+\mathrm{HCl}=1.5$ andalusite + 1.5 quartz $+1.5 \mathrm{H} 2 \mathrm{O}+\mathrm{KCl}$. For the $\mathrm{K}$-feldspar-muscovite-quartz-brine equilibrium, $\log 10$ $(\mathrm{KCl} / \mathrm{HCl})=1.6 \pm 0.1,0.81 \pm 0.06,0.54 \pm 0.04$ and $0.42 \pm 0.08$ at $25 \mathrm{MPa}$ and $400^{\circ} \mathrm{C}, 40 \mathrm{MPa}$ and $450^{\circ} \mathrm{C}, 50 \mathrm{MPa}$ and $500^{\circ} \mathrm{C}$, and $60 \mathrm{MPa}$ and $550^{\circ} \mathrm{C}$ (pressures and temperatures of the experiments), respectively. For the muscovite-andalusite-quartz-brine equilibrium, $\log 10$ $(\mathrm{KCl} / \mathrm{HCl})=0.63 \pm 0.1,-0.063 \pm 0.06,0.17 \pm 0.05$, and $0.25 \pm 0.08$ at the pressures and temperatures of the experiments, respectively. Comparison of our results with previous studies conducted at higher pressures and with lower-salinity aqueous phases show that the mineral 
stability fields in the $\mathrm{K}$-feldspar-muscovite-andalusite-quartz system shift to lower $\mathrm{KCl} / \mathrm{HCl}$ values with increasing salinity and decreasing pressure.

\section{Alkali exchange equilibria between a silicate melt and coexisting magmatic volatile phase: an experimental study at $800^{\circ} \mathrm{C}$ and $100 \mathrm{MPa}$}

Frank, M.R., Candela, P.A., and Piccoli, P.M.

Many experimental studies have been performed to evaluate the composition of coexisting silicate melts and magmatic volatile phases (MVP). However, few studies have attempted to define the relationship between melt chemistry and the acidity of a chloride-bearing fluid. Here we report data on melt composition as a function of the $\mathrm{HCl}$ concentration of coexisting brines. We performed 35 experimental runs with a $\mathrm{NaCl}-\mathrm{KCl}-\mathrm{HCl}-\mathrm{H}_{2} \mathrm{O}$ brine $(70 \mathrm{wt} \% \mathrm{NaCl}$ [equivalent])-silicate melt (starting composition of $\mathrm{Qtz}_{0.38} \mathrm{Ab}_{0.33} \mathrm{Or}_{0.29}$, anhydrous) assemblage at $800^{\circ} \mathrm{C}$ and $100 \mathrm{MPa}$. We determined an apparent equilibrium constant

$$
\mathrm{K}_{\text {meas }}^{\prime}(\mathrm{K}, \mathrm{Na})=\left(\mathrm{C}_{\mathrm{Na}}{ }^{\mathrm{m}} \times \mathrm{C}_{\mathrm{KCl}}{ }^{\mathrm{b}}\right) /\left(\mathrm{C}_{\mathrm{NaCl}}{ }^{\mathrm{b}} \times \mathrm{C}_{\mathrm{K}}{ }^{\mathrm{m}}\right)
$$

for the equilibrium

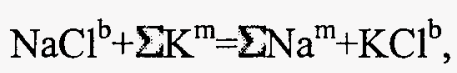

as a function of the $\mathrm{HCl}$ concentration in the brine $\left(\mathrm{C}_{\mathrm{HCl}}^{\mathrm{b}}\right)$. Although $\mathrm{K}_{\text {meas }}^{\prime}(\mathrm{K}, \mathrm{Na})$ was not affected by variations in $\mathrm{KCl} / \mathrm{NaCl}$ of the brine, it did vary inversely with $\mathrm{C}_{\mathrm{HCl}}{ }^{\mathrm{b}}$. The relationship is given by

$$
\mathrm{K}_{\mathrm{mes}}^{\prime}(\mathrm{K} \cdot \mathrm{Na})=\mathrm{K}_{\mathrm{ex}}^{*}(\mathrm{~K} \cdot \mathrm{Na})+\frac{\mathbf{a}}{\mathrm{C}_{\mathrm{HCl}}^{\mathrm{b}}}
$$


[where $\mathrm{C}_{\mathrm{HCl}}^{\mathrm{b}}$ is in wt\% and $a=0.03 ; \mathrm{K}_{\text {ex }}^{\prime}(\mathrm{K}, \mathrm{Na})=0.40 \pm 0.03(1 \sigma)$ and represents the exchange of model sodium and potassium between chloride components in the brine and the aluminate components $\left(\mathrm{NaAlO}_{2}\right.$ and $\left.\mathrm{KAlO}_{2}\right)$ in the melt. This empirical result will be discussed in light of a structural hypothesis; however, validation of the model awaits determinations based on spectroscopy or transport properties-thermodynamic relations alone cannot be used as evidence of structure. The form of this equation is consistent with a model wherein sodium is present in the melt as both sodium aluminate and sodium hydroxide components, and $\mathrm{HCl}$ reacts with the $\mathrm{NaOH}$ component in the melt to produce $\mathrm{NaCl}$ and $\mathrm{H}_{2} \mathrm{O}$.

The correlation between fugacity of $\mathrm{H}_{2} \mathrm{O}\left(\mathrm{fH}_{2} \mathrm{O}\right.$ sys $)$, model $\mathrm{NaOH}^{\mathrm{m}} / \Sigma \mathrm{Na}^{\mathrm{m}}$, aluminum saturation index (ASI), and the ratio $(\mathrm{HCl} / \mathrm{NaCl})^{\mathrm{b}}$ of an exsolving MVP is complex. $f \mathrm{H}_{20}$ sys and the ASI are the main controls on model $\mathrm{NaOH}^{\mathrm{m}} / \mathbf{\Sigma N a}{ }^{\mathrm{m}}$ in the system, with model $\mathrm{NaOH}^{\mathrm{m}} / \mathbf{\Sigma N a}^{\mathrm{m}}$ increasing with increasing $f \mathrm{H}_{2} \mathrm{O}$ sys. This relationship can be used to estimate the $\mathrm{C}_{\mathrm{HCl}}$ in subaluminous systems, an improvement over previous models. Data for metal partitioning between a volatile phase and melt are commonly presented in the literature as metal-sodium exchange equilibria (i.e., $\mathrm{K}_{\mathrm{Cu}, \mathrm{Na}}$ for the exchange of copper and sodium). However, the variation in $\mathrm{K}_{\text {meas }}^{\prime}(\mathrm{K}, \mathrm{Na})$ observed in this study implies that the treatment of metal partitioning between a volatile phase and melt as metal-alkali exchange equilibria is complex because alkali partitioning is not constant and suggests that experimental partitioning studies need to carefully control the $\mathrm{HCl} / \mathrm{NaCl}$ in experimental vapors and brines. This effect may explain discrepancies in metalalkali exchange equilibria presented in the literature. Therefore, metal-alkali exchange cannot be described fully by a single metal-alkali equilibrium but must be examined by multiple equilibria.

\section{Hydrogen-alkali exchange between silicate melts and two- phase aqueous mixtures: an experimental investigation}

Williams, T.J., Candela, P.A. and Piccoli, P.M.

Experiments were performed in the three-phase system high-silica rhyolite melt + low-salinity aqueous vapor + hydrosaline brine, to investigate the exchange equilibria for hydrogen, 
potassium, and sodium in magmatic-hydrothermal systems at $800^{\circ} \mathrm{C}$ and $100 \mathrm{MPa}$, and $850{ }^{\circ} \mathrm{C}$ and $50 \mathrm{MPa}$. The $\mathrm{K}_{\mathrm{H}, \mathrm{Na}}^{\mathrm{aqm} / \mathrm{melt}}$ and $\mathrm{K}_{\mathrm{H}, \mathrm{K}}^{\text {aqm/melt }}$ for hydrogen-sodium exchange between a vapor + brine mixture and a silicate melt are inversely proportional to the total chloride concentration $(+\mathrm{Cl})$ in the vapor + brine mixture indicating that $\mathrm{HCl} / \mathrm{NaCl}$ and $\mathrm{HCl} / \mathrm{KCl}$ are higher in the lowsalinity aqueous vapor relative to high-salinity brine. The equilibrium constants for vapor/melt and brine/melt exchange were extracted from regressions of $\mathrm{K}^{\text {aqm/melt }}{ }_{\mathrm{H}, \mathrm{Na}}$ and $\mathrm{K}^{\mathrm{aqm} / \mathrm{melt}}{ }_{\mathrm{H}, \mathrm{K}}$ versuS the proportion of aqueous vapor relative to brine in the aqueous mixture $\left(\mathrm{F}^{\mathrm{anv}}\right)$ at $\mathrm{P}$ and $\mathrm{T}$, expressed as a function of $\$ \mathrm{Cl}$. No significant pressure effect on the empirically determined exchange constants was observed for the range of pressures investigated. Model equilibrium constants are: $\mathrm{K}_{\mathrm{H}, \mathrm{Na}}^{\text {aqv/melt }}($ vapor/melt $)=26(-1.3)$ at $100 \mathrm{MPa}\left(800^{\circ} \mathrm{C}\right)$, and $19(-7.0)$ at $50 \mathrm{MPa}$ $\left(850^{\circ} \mathrm{C}\right) ; \mathrm{K}_{\mathrm{H}, \mathrm{K}}^{\text {aqv/melt }}=14(-1.1)$ at $100 \mathrm{MPa}\left(800^{\circ} \mathrm{C}\right)$, and $24(-12)$ at $50 \mathrm{MPa}\left(850^{\circ} \mathrm{C}\right)$;

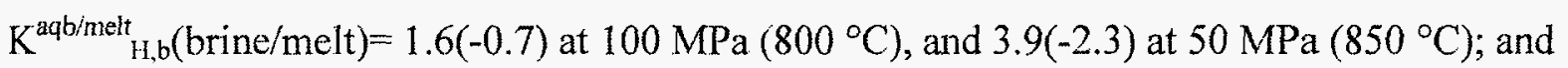
$\mathrm{K}_{\mathrm{H}, \mathrm{K}}^{\mathrm{aqb} / \mathrm{melt}}=2.7(-1.2)$ at $100 \mathrm{MPa}\left(800^{\circ} \mathrm{C}\right)$ and $3.8(-2.3)$ at $50 \mathrm{MPa}\left(850^{\circ} \mathrm{C}\right)$. Values for $\mathrm{K}_{\mathrm{H}, \mathrm{K}}^{\mathrm{aqu} / \mathrm{melt}}$ and $\mathrm{K}_{\mathrm{H}, \mathrm{K}}^{\mathrm{aqb} / \mathrm{melt}}$ were used to calculate $\mathrm{KCl} / \mathrm{HCl}$ in the aqueous vapor and brine as a function of melt aluminum saturation index (ASI: molar $\mathrm{Al}_{2} \mathrm{O}_{3} /\left(\mathrm{K}_{2} \mathrm{O}+\mathrm{Na}_{2} \mathrm{O}+\mathrm{CaO}\right)$ and pressure. The model $\log \mathrm{KCl} / \mathrm{HCl}$ values show that a change in melt ASI from peraluminous $(\mathrm{ASI}=1.04)$ to moderately metaluminous $(\mathrm{ASI}=1.01)$ shifts the cooling pathway (in temperature-log $\mathrm{KCl} / \mathrm{HCl}$ space) of the aqueous vapor toward the andalusite + muscovite $+\mathrm{K}$-feldspar reaction point.

\section{Estimation of aqueous $\mathrm{HCl}$ and $\mathrm{Cl}$ concentrations in felsic systems}

Piccoli, P.M., Candela, P.A. and Williams, T.J.

Two models are presented which can be used to make order of magnitude estimates of the concentration of $\mathrm{HCl}$ and $\mathrm{Cl}$ in the magmatic volatile phase (MVP). One model is based primarily upon aplite chemistry, and the other is based primarily on apatite chemistry; the models are not entirely independent, and additional information can be gained by using the models in conjunction with one another. Combining both methods allows for the calculation of a model 
bulk $\mathrm{Cl}$ concentration of magmatic vapor. Both models are applied to a natural system: the Billy Lake granite and Rush Creek quartz-monzodiorite in the Sierra Nevada Batholith of eastern California. The bulk composition of aplite and other granitic rocks of (vapor-saturated) nearminimum melt compositions can be used to estimate maximum $\mathrm{HCl} /$ total $\mathrm{Cl}$ for the magmatic vapor phase. The composition of the aplites in the Billy Lake-Rush Creek (BLRC) system has been used to determine model $\mathrm{HCl} / \mathrm{KCl}$ and $\mathrm{HCl} / \mathrm{NaCl}$ for the vapor in equilibrium with the aplite melts; both ratios are on the order of unity (1.1). These values suggest that the maximum $\mathrm{HCl} / \mathrm{Cl} 1 / 3$, corresponding to a concentration of $\mathrm{HCl}$ in the magmatic vapor of $\sim 0.02$ molal if the magmatic system was saturated with a brine phase. Apatite compositions can be used to estimate the $\mathrm{HCl}$ concentration in the magmatic vapor as a function of temperature. Based on the $\mathrm{P}_{2} \mathrm{O}_{5}$ and $\mathrm{SiO}_{2}$ concentrations in the aplites, and the solubility of apatite in silicate melts, apatite began to crystallize at $820^{\circ} \mathrm{C}$ in the aplites, which also yields an estimate of 0.02 molal for the concentration of $\mathrm{HCl}$ for the BLRC system by the apatite method. Within error, both models produce the some result. 


\section{Select References:}

Frank, M.R., Candela, P.A., and Piccoli, P.M. (2001) Alkali exchange equilibria between a silicate melt and coexisting magmatic volatile phase: an experimental study at $800^{\circ} \mathrm{C}$ and 100 MPa. Geochimica et Cosmochimica Acta

Frank, M.R., Candela, P.A. and Piccoli, P.M. (1998) K-feldspar-muscovite-andalusite-quartzbrine phase equilibria: an experimental study at 25-60 MPa and $400-550^{\circ} \mathrm{C}$. Geochimica et Cosmochimica Acta, 62, 3717-3727.

Hall, M.S. (1999) Reactions between a sulfate-bearing, vapor undersaturated brine and the mineral assemblage potassium feldspar-albite-quartz-tremolite-apatite at $500^{\circ} \mathrm{C}$ and $50 \mathrm{MPa}$. University of Maryland, M.S. Thesis.

Piccoli, P.M., Candela, P.A. and Williams, T.J. (1999) Constraints on Estimating $\mathrm{HCl}$ and $\mathrm{Cl}$ in the Magmatic Volatile Phase in Granites and Granite-Related Ore Systems: A Potential Tool for the Estimation of High- and Low-Cl Systems. Second International Symposium on Granites and Associated Mineralizations; Salvador, Brazil. Published in a special issue of Lithos, 46, 573-589

Williams, T.J., Candela, P.A. and Piccoli, P.M. (1997) Hydrogen-alkali exchange between silicate melts and two-phase aqueous mixtures: an experimental investigation. Contributions to Mineralogy and Petrology 128, 114-126. 